\title{
Breast Cancer: State of the Art and New Findings
}

\author{
Das Mammakarzinom: State of the Art und Neuigkeiten
}

Authors

Affiliations
C. Melcher ${ }^{1}$, C. Scholz ${ }^{1}$, B. Jäger ${ }^{2}$, C. Hagenbeck ${ }^{1}$, B. Rack ${ }^{2}$, W. Janni ${ }^{1}$

${ }^{1}$ Women's Clinic, Hospital of the Heinrich Heine University of Düsseldorf, Düsseldorf

2 Department and Outpatient Clinic for Gynaecology and Obstetrics - Innenstadt, Hospital of the Ludwig Maximilian University of Munich, Munich

\section{Key words}

- breast cancer

- molecular genetic subtypes

- chemotherapy

- targeted therapy

- endocrine therapy

- radiotherapy

$\checkmark$ prognosis

\section{Schlüsselwörter}

- Mammakarzinom

- molekulargenetische Subtypen

- Chemotherapie

- zielgerichtete Therapie

- endokrine Therapie

- Radiotherapie

- Prognose

\section{Abstract \\ $\nabla$}

Advances in research have a highly influential role to play in the strategy of early detection, treatment and aftercare of breast cancer and therefore everyday clinical practice. Newly-defined prognosis factors and a new form of molecular subtype classification, for example, are intended to help identify patients who will actually benefit from chemotherapy. In the field of neoadjuvant chemotherapy, the inclusion of the angiogenesis inhibitor Bevacizumab and dual antiHER2 therapy is being discussed. What's more, where defined criteria are met, even with positive sentinel lymph nodes, axillary dissection is not performed; besides bisphosphonates RANKL antibody Denosumab is now an option in the treatment of bone metastases.

\section{Zusammenfassung \\ $\nabla$}

Die Fortschritte in der Forschung beeinflussen maßgeblich die Strategie der Früherkennung, Behandlung und Nachsorge des Mammakarzinoms und damit den klinischen Alltag. Neu definierte Prognosefaktoren sowie eine neue molekulare Subtypen-Klassifikation sollen helfen, Patientinnen zu identifizieren, die tatsächlich von einer Chemotherapie profitieren werden. Im Bereich der neoadjuvanten Chemotherapie werden die Hinzunahme des Angiogenesehemmers Bevacizumab und eine duale Anti-HER2-Therapie diskutiert. Zudem darf beim Vorliegen definierter Kriterien auch bei positivem Sentinellymphknoten auf eine Axilladissektion verzichtet werden, und bei der Behandlung ossärer Metastasen steht uns nun neben den Bisphosphonaten der RANKL-Antikörper Denosumab zur Verfügung.

\section{received 22.12.2011 \\ revised $\quad 12.3 .2012$ \\ accepted $\quad 12.3 .2012$}

Bibliography

DoI http://dx.doi.org/ 10.1055/s-0031-1298320

Geburtsh Frauenheilk 2012; 72 :

215-224 (c) Georg Thieme

Verlag KG Stuttgart · New York · ISSN 0016-5751

\section{Correspondence}

Dr. Carola Melcher

Women's Clinic

Hospital of the Heinrich Heine

University of Düsseldorf

Moorenstraße 5

40225 Düsseldorf

carola.melcher@

med.uni-duesseldorf.de

\section{Pathology of Breast Cancer}

$\nabla$

\section{Classification - expansion with}

molecular genetic subtypes

Breast cancer is being classified, as previously, using the TNM classification system, which is supplemented by the histological grading $(G)$, the involvement of lymph vessels ( $\mathrm{L}$ ) and blood vessels (V), as well as by the hormone receptor status (ER and PR) and the HER2/neu status.

Most recently, researchers have been using a molecular classification system of mRNA expression profiles into four types. This classification has the potential to differentiate among future patients who will actually benefit from chemotherapy and those for whom chemotherapy would represent excessive treatment (cf. $\bigcirc$ Table 1).

\section{The proliferation marker Ki-67}

The Ki-67 protein is expressed in human cells throughout the entire cell division cycle. Its ab-
Pathologie des Mammakarzinoms $\nabla$

Klassifikation - Erweiterung durch molekulargenetische Subtypen

Die Einteilung des Mammakarzinoms erfolgt nach wie vor anhand der TNM-Klassifikation, die ergänzt wird durch das histologische Grading (G), den Befall von Lymphbahnen (L) und Blutgefäßen (V) sowie durch den Hormonrezeptorstatus (ER und PR) und den HER2/neu Status.

Neu hinzugekommen ist eine molekulare Klassifikation über mRNA-Expressionsprofile in 4 Typen. Diese Einteilung hat das Potenzial, zukünftig jene Patientinnen voneinander zu differenzieren, die tatsächlich von einer Chemotherapie profitieren und solchen, die durch eine Chemotherapie übertherapiert wären (vgl. $\odot$ Tab. 1).

\section{Der Proliferationsmarker Ki-67}

Das Protein Ki-67 wird während des gesamten aktiven Zellteilungszyklus in menschlichen Zellen expri- 
Table 1 St. Gallen consensus 2011: Subtypes of breast cancer and therapeutic options [1].

\begin{tabular}{|c|c|c|c|c|c|c|c|}
\hline & ER & PR & Ki-67 & HER2/neu & Endocrine therapy & Chemotherapy & Anti-HER2 therapy \\
\hline Luminal A & + & + & $<14 \%$ & - & + & - & - \\
\hline \multirow[t]{2}{*}{ Luminal B } & + & + or- & $\geq 14 \%$ & - & + & + & - \\
\hline & + & +or- & every value & + & + & + & + \\
\hline HER2-positive & - & - & every value & + & - & + & + \\
\hline Basal-like & - & - & every value & - & - & + & - \\
\hline
\end{tabular}

sence in inactive cells makes Ki-67 an excellent marker for the proliferation rate of a tumour [2]. Luminal A tumours, for example, which exhibit a low division rate with positive hormone receptors, have a poor response to chemotherapy. At the same time, their tumour biology indicates a favourable prognosis. Based on the results of a meta-analysis, the consensus meeting in St. Gallen recommends a cut-off value of $14 \%$. The importance of Ki-67 is regarded as controversial, particularly in light of methodological considerations, and is evaluated differently in different guidelines [3].

\section{Prognosis factors and predictive factors}

The classical prognosis factors and predictive factors continue to remain the focus for individual treatment decisions: grading, hormone receptor status, HER2/neu status, age and lymph node status. The patient's individual risk and the presumed therapeutic benefits of treatment can be approximated by entering the classical prognosis factors into a calculation program (e.g. www. adjuvantonline.com).

As well as the classical pathological criteria, new prognostic factors are also being included in the decision-making process ( Table 2). The identification of selected proteases is performed using fresh tumour tissue. These are specific proteins that are responsible for the invasion and transport of tumour cells. The identification process is intended to better identify patients who will actually benefit from chemotherapy.

\section{What's new?}

According to current AGO recommendations, UPA/PAI-1 are valid and evidence-based prognostic and prediction factors for patients with node-negative breast cancer and an intermediate risk profile (e.g. pN0 G2) [4].

Circulating tumour cells (CTC) can be identified in peripheral blood using the CellSearch ${ }^{\circledR}$ system. Based on the work by Cristofanilli et al., the CellSearch ${ }^{\circledR}$ system has been approved by the FDA for use in metastatic breast cancer. Metastasised patients with circulating tumour cells exhibit a significantly lower overall survival rate and progression-free survival rate [5]. Even in neo-

Table 2 New prognostic factors for breast cancer.

\footnotetext{
New prognostic factors

- Tumour-associated proteolysis factors (uPA and PAI-1)

- Proliferation markers (e.g. Ki-67)

- Disseminated/circulating tumour cells

Tests on genetic signatures

- Amsterdam 70-Gene Signature (Mammaprint ${ }^{\circledR}$ )

- 21-Gene Recurrence Score (RS) Assay (Oncotype DX ${ }^{\circledR}$ )

- 50-Gene qRT-PCR Classifier (PAM50 ${ }^{\circledR}$ )
}

uPA: Urokinase-type plasminogen factor; PAI-1 plasminogen activator inhibitor type 1 miert. Seine gleichzeitige Abwesenheit in inaktiven Zellen macht Ki67 zu einem exzellenten Marker für die Proliferationsrate eines Tumors [2]. So sprechen Luminal-A-Tumoren, die bei positiven Hormonrezeptoren eine niedrige Teilungsrate aufweisen, ungenügend auf eine Chemotherapie an. Gleichzeitig spricht ihre Tumorbiologie für eine günstige Prognose. Basierend auf den Ergebnissen einer Metaanalyse empfiehlt das Konsensusmeeting in St. Gallen einen Cuf-off-Wert von 14\%. Der Stellenwert von Ki-67 wird vor allem auch vor dem Hintergrund von methodologischen Überlegungen kontrovers eingeschätzt und wird in unterschiedlichen Leitlinien divergent bewertet [3].

\section{Prognosefaktoren und prädiktive Faktoren}

Für die individuelle Therapieentscheidung stehen weiterhin die klassischen Prognosefaktoren und prädiktiven Faktoren im Fokus: Grading, Hormonrezeptorstatus, HER2/neu-Status, Alter und Lymphknotenstatus. Das individuelle Risiko der Patientin und auch der zu vermutende therapeutische Nutzen einer Behandlung kann durch Eingabe der klassischen Prognosefaktoren in ein Kalkulationsprogramm approximiert werden (z. B. www.adjuvantonline.com).

Neben den klassischen pathologischen Kriterien werden neue Prognosefaktoren in die Entscheidungsfindung einbezogen ( Tab.2). Die Bestimmung ausgewählter Proteasen erfolgt aus frischem Tumorgewebe. Dabei handelt es sich um bestimmte Eiweißstoffe, die für die Invasion und Verschleppung von Tumorzellen verantwortlich sind. Die Bestimmung soll der besseren Identifizierung von Patientinnen dienen, die tatsächlich von einer Chemotherapie profitieren werden.

\section{Was ist neu?}

Laut der aktuellen AGO-Empfehlung sind UPA/PAI-1 valide und evidenzbasierte Prognose- und Prädiktionsfaktoren für Patientinnen mit nodal-negativem Mammakarzinom und intermediärem Risikoprofil (z. B. pNO G2) [4]

Zirkulierende Tumorzellen (CTC) lassen sich mithilfe des CellSearch ${ }^{\circledR}$ Systems im peripheren Blut nachweisen. Auf der Basis der Arbeiten von Cristofanilli et al. ist das CellSearch ${ }^{\circledR}$-System von der FDA für den Einsatz beim metastasierten Mammakarzinom zugelassen. Dabei zeigen metastasierte Patientinnen mit zirkulierenden Tumorzellen ein signifikant schlechteres Gesamtüberleben und progressionsfreies Überleben [5]. Auch in der neoadjuvanten und adjuvanten Situation belegen aktuelle Daten die prognostische Relevanz der CTC [6, 7]. In Fällen mit grenzwertigem Therapiebenefit werden zunehmend sog. Genexpressionsanalysen eingesetzt. Dabei wird die Genaktivität der Tumorzellen analysiert und somit eine Aussage über das individuelle Risikoprofil der Patientin getroffen. Der generelle Einsatz der Gentests wird bislang seitens der AGO nicht empfohlen, bis weitere Klärung durch Studiendaten erfolgt. 
adjuvant and adjuvant situations, current data confirms the prognostic relevance of CTC [6,7].

In cases with borderline therapeutic benefit, gene expression analyses are increasingly being used. With these, the genetic activity of the tumour cells is analysed to provide information about the patient's individual risk profile. The general use of genetic testing has so far not been recommended by the AGO until it has been further clarified with study data.

\section{Treatment of Primary Breast Cancer}

\section{Neoadjuvant therapy}

The inevitable indication for pre-operative systemic therapy stands for primary inoperable and extremely advanced and inflammatory breast cancers [8]. It is also a possible treatment for all patients in whom the indication for systemic therapy essentially exists, and can increase the number of breast-conserving operations [9]. One crucial advantage of primary systemic therapy is the ability to evaluate the effectiveness of the treatment using mammary ultrasound, palpation and/or mammography. Following primary removal of the tumour, this option no longer exists.

Numerous studies have shown that the safety of neoadjuvant therapy is equivalent to adjuvant chemotherapy [10]. Neoadjuvant chemotherapy should include both a taxane and an anthracycline and be given pre-operatively for at least 6 cycles (18 weeks). Where there is overexpression of HER2/neu, Trastuzumab therapy combined with chemotherapy is recommended and should be completed over a total period of 1 year after chemotherapy has finished [4].

Patients with complete pathological remission of the primary tumour $(\mathrm{pCR}=$ no evidence of tumour cells in the breast or axilla) have the best prognosis $[9,11]$. Specific factors can be defined for predicting a good response to neoadjuvant chemotherapy (OTable 3).

Following completion of the treatment, the patient should have surgery 2-4 weeks after the last chemotherapy cycle (see the section entitled "Surgical treatment"); precise documentation of the tumour localisation before, during and after the completion of neoadjuvant chemotherapy is essential. During the resection, orientation towards the new tumour borders is possible if an R0 resection can be achieved with an adequate safety margin [12]. Where there is clinical complete remission, the excision should be orientated towards the borders of the previous tumour localisation in order to clarify whether there are still living tumour cells in the tumour bed [13]. In principle, the extent of the local operation and the axillary dissection represent an issue that is the subject of much scientific debate in the concept of breast cancer as a systemic disease and should be discussed on a case-by-case basis.

\section{What's new?}

There is new data from two major studies into neoadjuvant therapy. The data from the German GeparQuinto study shows that the sub-collective of triple-negative patients (base type, cf. - Table 1) benefit from the addition of the angiogenesis inhibitor Bevacizumab (significantly higher pCR rate [36.5 vs. $27.8 \%$, $p=0.021]$ ). The evaluation of NSABP B-40, through the use of Bevacizumab $(p=0.027)$ confirmed a significantly higher $p C R$ rate among hormone receptor-positive patients $(p=0.008)$, albeit at the cost of greater toxicity.
Table 3 Predictive factors for a good response to neoadjuvant chemotherapy.

Factors that predict a good response to neoadjuvant chemotherapy:

- Age ( $<35$ years)

- cT1/cT2 tumours

- Negative nodal status

- Grade 3 tumours

- Negative hormone receptor status

- Positive HER2/neu status

\section{Therapie des primären Mammakarzinoms}

\section{$\nabla$}

\section{Neoadjuvante Therapie}

Die obligate Indikation zur präoperativ systemischen Therapie besteht für primär inoperable, sehr fortgeschrittene und inflammatorische Mammakarzinome [8]. Sie ist außerdem eine Behandlungsmöglichkeit für alle Patientinnen, bei denen grundsätzlich die Indikation zur Systemtherapie besteht, und kann die Rate brusterhaltender Operationen erhöhen [9]. Ein entscheidender Vorteil einer primär systemischen Therapie ist, das Therapieansprechen mittels Mammasonografie, Palpation und/oder Mammografie evaluieren zu können. Nach primärer Entfernung des Tumors entfällt diese Möglichkeit.

In zahlreichen Studien konnte gezeigt werden, dass die Sicherheit einer neoadjuvanten Therapie der einer adjuvanten Chemotherapie entspricht [10]. Die neoadjuvante Chemotherapie sollte sowohl ein Taxan als auch ein Anthrazyklin enthalten und über mindestens $6 \mathrm{Zy}$ klen (18 Wochen) präoperativ gegeben werden. Bei HER2/neu-Überexpression wird die Trastuzumab-Therapie kombiniert mit Chemotherapie empfohlen und sollte nach Abschluss der Chemotherapie mit einem Gesamtzeitraum von 1 Jahr komplettiert werden [4]. Patientinnen mit einer kompletten pathologischen Remission des Primärtumors ( $\mathrm{pCR}=$ kein Tumorzellnachweis in der Brust und der Axilla) weisen die beste Prognose auf $[9,11]$. Es lassen sich dabei definierte Faktoren benennen, die ein gutes Ansprechen auf die neoadjuvante Chemotherapie vorhersagen (OTab. 3).

Nach Abschluss der Therapie sollte die Patientin 2-4 Wochen nach dem letzten Chemotherapiezyklus operiert werden (siehe Abschnitt „Operative Therapie“); entscheidend ist die präzise Dokumentation der Tumorlokalisation vor, während und nach Ende der neoadjuvanten Chemotherapie. Bei der Resektion ist eine Orientierung an den neuen Tumorgrenzen möglich, wenn dadurch eine R0-Resektion mit ausreichend Sicherheitsabstand erreicht werden kann [12]. Bei einer klinischen Komplettremission sollte sich die Exzision an den Grenzen der vormaligen Tumorlokalisation orientieren, um abzuklären, ob noch vitale Tumorzellen im Tumorbett nachzuweisen sind [13]. Prinzipiell ist das Ausmaß der lokalen Operation sowie der Axilladissektion eine im Konzept des Mammakarzinoms als Systemerkrankung wissenschaftlich viel diskutierte Fragestellung und sollte im individuellen Fall diskutiert werden.

\section{Was ist neu?}

In der neoadjuvanten Therapie gibt es neue Daten aus 2 großen Studien. Die Daten der deutschen GeparQuinto-Studie zeigen, dass das Subkollektiv der triple-negativen Patientinnen (Basaltyp, vgl. @ Tab. 1) von der Hinzunahme des Angiogenesehemmers Bevacizumab profitieren (signifikant höhere pCR-Rate $[36,5$ vs. $27,8 \%, p=0,021])$. Die Auswertung der NSABP B-40 konnte durch den Einsatz von Bevacizumab $(p=0,027)$ eine signifikant höhere $P C R$-Rate bei den hormonrezeptorpositiven Patientinnen $(p=0,008)$ belegen, allerdings auf Kosten einer höheren Toxizität. 
The results from the GeparTrio study, which were presented at the San Antonio Breast Cancer Symposium in 2011, also show that the achievement of one PCR for the basal-like subtype and for HER2/neu-positive patients represents a prognostic factor for a longer, disease-free survival. This does not apply, however, for Luminal A tumours [14].

\section{Surgical treatment}

The aim of surgical treatment is to completely remove the tumour with a tumour-free resection margin (R0). The microscopically-measured safety margin between the tumour and the resection edge should be $\geq 1 \mathrm{~mm}$ for invasive carcinoma [15].

Data shows that the overall survival rate following breast-conserving therapy (BCT) followed by radiation or after sole modified radical mastectomy (MRM) is the same $[16,17]$. MRM involves complete removal of the mammary gland and nipple, plus removal of the fascia of the pectoralis major muscle. Thanks to the introduction of mammography screening for the early detection of breast cancer, the proportion of small tumours out of all of the newly-diagnosed tumours has risen markedly; as has the proportion of tumours that can be operated on and allow the breast to be conserved. Currently, around $70 \%$ of breast cancers are operated on with conservation of the breast. Where defined criteria are met, however, mastectomy continues to be indicated ( Table 4). If the skin is not affected, a skin-sparing mastectomy (SSM) can be performed and the risk of local recurrence is equivalent to that of the MRM; the same applies in individual cases where the tumour is located far from the nipple and even with breast-conserving procedures. Reconstruction of the breast using silicone implants (if no post-operative radiotherapy is required) or autologous tissue is then made easier. An immediate reconstruction of the breast does not adversely affect the prognosis and is a possible standard. A secondary reconstruction can, however, also be carried out at a later point in time.

Where there is a non-palpable lesion present pre-operatively, the lesion must be localised using wire marking and removed using this marking as a guide $[18,19]$. The preparation removed should be checked using an imaging method suitable for the marking technique (e.g. preparation radiography) to ensure completeness with regard to the pre-operative findings.

\section{Lymph nodectomy}

Using sentinel lymph nodectomy (SLNE), the determination of the histological nodal status (pN status) should be carried out as part of the surgical treatment. If the lymph node is free from tumour, no further lymph nodes are removed. As soon as lymph node involvement is detected, however, a total of at least 10 lymph nodes from levels I and II are removed as part of an axillary dissection. The SLNE and axillary dissection are equal in terms of the local control of tumour spread $[20,21]$. However, the shoulder/arm morbidity and risk of lymphoedema following SLNE are significantly reduced [22].

Table 4 Indications for mastectomy.
A mastectomy is required
- where there is multi-centricity
- for an unfavourable breast/tumour size ratio
- where there is ulceration of the tumour
- where there is inflammatory breast cancer
- if the patient requests it (e.g. if they do not want follow-on radiotherapy)

Ergebnisse der GeparTrio-Studie, die beim San Antonio Breast Cancer Symposium 2011 vorgestellt wurden, zeigen außerdem, dass das Erreichen einer PCR beim Basaltyp und bei HER2/neupositiven Patientinnen ein Prognosefaktor für ein längeres krankheitsfreies Überleben darstellt. Dies gilt hingegen nicht für Luminal-A-Tumoren [14].

\section{Operative Therapie}

Ziel der operativen Therapie ist die vollständige Entfernung des Tumors mit einem tumorfreien Resektionsrand (RO). Der mikroskopisch gemessene Sicherheitsabstand zwischen Tumor und Resektionsrand sollte $\geq 1 \mathrm{~mm}$ für das invasive Karzinom betragen [15]. Daten zeigen, dass das Gesamtüberleben nach brusterhaltender Therapie (BET) mit nachfolgender Bestrahlung oder nach alleiniger modifiziert radikaler Mastektomie (MRM) gleichwertig ist [16,17]. Die MRM umfasst eine komplette Entfernung der Brustdrüse mit Brustwarze unter Mitnahme der Faszie des M. pectoralis major. Durch die Einführung des Mammografie-Screenings zur Brustkrebsfrüherkennung ist der Anteil kleiner Tumoren an den insgesamt neu diagnostizierten Tumoren deutlich gestiegen; ebenso der Anteil der Tumoren, die brusterhaltend operiert werden können. Derzeit werden etwa 70\% der Mammakarzinome brusterhaltend operiert. Bei definierten Kriterien ist jedoch weiterhin eine Mastektomie indiziert (๑ Tab.4). Solange die Haut nicht befallen ist, ist die Durchführung einer hautsparenden Mastektomie (SSM = skin sparing mastectomy) möglich und bez. des Risikos von Lokalrezidiven äquivalent mit der MRM; in Einzelfällen bei brustwarzenfernem Tumorsitz sogar brustwarzenerhaltend. Eine Rekonstruktion der Brust mittels Silikonimplantaten (wenn keine postoperative Strahlentherapie notwendig ist) oder durch Eigengewebe ist dann erleichtert. Eine Sofortrekonstruktion der Brust verschlechtert nicht die Prognose und ist ein möglicher Standard. Eine 2-zeitige (sekundäre) Rekonstruktion kann jedoch auch zu einem späteren Zeitpunkt erfolgen.

Bei einer präoperativ nicht palpablen Läsion muss diese durch eine Drahtmarkung lokalisiert und anhand dieser Markierung exstirpiert werden $[18,19]$. Das entnommene Präparat ist mit Hilfe eines der Methodik der Markierung entsprechenden bildgebenden Verfahrens (z.B. Präparatradiografie) auf Vollständigkeit bez. des präoperativen Befundes zu überprüfen.

\section{Lymphonodektomie}

Mithilfe der Sentinellymphonodektomie (SLNE) sollte die Bestimmung des histologischen Nodalstatus (pN-Status) als Bestandteil der operativen Therapie erfolgen. Wenn der Lymphknoten tumorfrei ist, werden keine weiteren Lymphknoten entfernt. Sofern jedoch ein Lymphknotenbefall nachgewiesen wird, werden im Rahmen einer Axilladissektion insgesamt mindestens 10 Lymphknoten aus Level I und II entfernt. Die SLNE und die Axilladissektion sind in der lokalen Kontrolle der Tumorausbreitung gleichwertig [20,21]. Die SchulterArm-Morbidität und das Risiko für ein Lymphödem nach SLNE sind hingegen signifikant reduziert [22]. 
What's new?

A feature of the latest discussions is the question of whether a complete axillary dissection is necessary where there are positive sentinel lymph nodes. Based on the results of two new studies (NSABP-32 study [23] and ACOSOG Z0011 [24]), the AGO has given its positive recommendation for not performing axillary dissection, provided all of the following conditions are met:

- $\mathrm{cT} 1 / 2$

$-\mathrm{CNO}$

$-<3$ affected lymph nodes

- BCT + tangential radiation

- Adequate systemic therapy

Moreover, if there is minimal involvement by micrometastasis ( $<2 \mathrm{~mm}$, but $>0.2 \mathrm{~mm}$, tumour formula $\mathrm{N} 1 \mathrm{mi}$ ) and subsequent breast radiation, an axillary dissection does not need to be carried out [25]. In patients who have had mastectomies and who have positive sentinel lymph nodes, axillary dissection continues to be indicated. Axillary staging is not indicated in stage M1. Where there are plans to perform neoadjuvant chemotherapy, axillary staging can be carried out before systemic therapy is commenced (e.g. as part of a port insertion).

\section{Systemic adjuvant therapy}

Before systemic adjuvant therapy is commenced, an individual risk/benefit analysis should be carried out in which the benefit of survival is weighed up against the side effects caused by the treatment. In principle, a systemic treatment decision should be made for each patient based on their individual tumour biology. Only in cases of less aggressive disease can chemotherapy be foregone (see above, $\bullet$ Table 1 ). In this case, the following criteria should generally be met:

- N0 (tumour-free lymph nodes)

- Positive oestrogen and/or progesterone receptor status

- Grade 1

- Tumour size $<2 \mathrm{~cm}$

- Age $>35$ years

- No HER2/neu overexpression

Where the hormone receptor status is positive, adjuvant endocrine therapy should be given in all cases. This is commenced where chemotherapy is being given after the end of the cytostatic treatment.

The chemotherapy should generally be started two to four weeks after surgery and once the wound has healed. The numerous treatment schedules generally contain an anthracycline and a taxane. They are combined with ingredients from other drug groups, e.g. with an alkylating agent and an anti-metabolite. The standard therapy today is anthracycline chemotherapy supplemented either simultaneously or sequentially with a taxane. This is proven to reduce the risk of recurrence and improves overall survival rates [26]. According to the current set of data, the PACS-01 schedule $(3 \times$ FEC, followed by $3 \times$ Doc), EC-Doc $(4 \times$ EC, followed by $4 \times$ Doc), the TAC schedule $(6 \times$ Doc + Doxorubicin + Cyclophosphamide) and AC-Pw (4× Doxorubicin + Cyclophosphamide, followed by $12 \times$ Paclitaxel weekly) are the most effective forms of treatment [27].
Was ist neu?

Bestandteil aktueller Diskussionen ist die Frage, ob bei positivem Sentinellymphknoten eine komplette Axilladissektion erforderlich ist. Basierend auf den Ergebnissen zweier neuer Studien (NSABP-32-Studie [23] sowie ACOSOG Z0011 [24]) gibt es durch die AGO eine positive Empfehlung zum Verzicht auf die Axilladissektion, sofern alle folgenden Bedingungen zutreffen:

- $\mathrm{cT} 1 / 2$

$-\mathrm{cNO}$

- <3 befallene Lymphknoten

- BET + tangentiale Bestrahlung

- adäquate Systemtherapie

Außerdem darf bei minimalem Befall durch eine Mikrometastase ( $<2 \mathrm{~mm}$, aber $>0,2 \mathrm{~mm}$, Tumorformel $\mathrm{N} 1 \mathrm{mi}$ ) und nachfolgender Brustbestrahlung auf eine Axilladissektion verzichtet werden [25]. Bei mastektomierten Patientinnen mit positivem Sentinellymphknoten ist eine Axilladissektion weiterhin indiziert. Im Stadium M1 ist ein axilläres Staging nicht indiziert. Bei geplanter neoadjuvanter Chemotherapie kann das axilläre Staging vor Beginn der Systemtherapie (z.B. im Rahmen einer Portanlage) erfolgen.

\section{Systemische adjuvante Therapie}

Vor Beginn einer systemischen adjuvanten Therapie sollte eine individuelle Nutzen-Risiko-Bewertung erfolgen, wobei der Überlebensvorteil gegenüber den entsprechenden therapiebedingten Nebenwirkungen abgewogen wird. Prinzipiell sollte für jede Patientin eine der individuellen Tumorbiologie angepasste systemische Therapieentscheidung getroffen werden.

Nur bei wenig aggressiver Erkrankung kann auf eine Chemotherapie verzichtet werden (s.a. @ Tab. 1). Hier sollten in der Regel folgende Kriterien erfüllt sein:

- N0 (tumorfreie Lymphknoten)

- positiver Östrogen- und/oder Progesteronrezeptorstatus

- Grading 1

- Tumorgröße $<2 \mathrm{~cm}$

- Alter $>35$ Jahre

- keine HER2/neu-Überexpression

Bei positivem Hormonrezeptorstatus sollte auf jeden Fall eine adjuvante endokrine Therapie erfolgen. Diese wird bei Durchführung einer Chemotherapie nach Ende der zytostatischen Behandlung begonnen.

Die Chemotherapie sollte in der Regel etwa 2-4 Wochen nach der Operation und Abschluss der Wundheilung beginnen. Die zahlreichen Therapieschemata enthalten in aller Regel ein Anthrazyklin und ein Taxan. Dabei werden sie mit Wirkstoffen anderer Stoffgruppen kombiniert, z. B. mit einem Alkylans und einem Antimetaboliten. Standardtherapie ist heute eine Anthrazyklin-Chemotherapie entweder simultan oder sequenziell durch ein Taxan ergänzt. Dies senkt nachweislich das Rezidivrisiko und verbessert das Gesamtüberleben [26]. Nach der derzeitigen Datenlage sind das PACS-01 Schema ( $3 \times$ FEC, gefolgt von $3 \times$ Doc), EC-Doc ( $4 \times$ EC, gefolgt von $4 \times$ Doc), das TAC-Schema (6× Doc + Doxorubicin + Cyclophosphamid) sowie AC-Pw ( $4 \times$ Doxorubicin + Cyclophosphamid, gefolgt von $12 \times$ Paclitaxel weekly) die effektivsten Therapieformen [27]. 


\section{What's new?}

Studies are currently investigating the effectiveness of anthracycline-free schedules (e.g. 6 cycles of Docetaxel and Cyclophosphamide) in patients with HER2/neu-negative breast cancer in order to avoid the long-term side effects (especially cardio-toxicity) of the anthracyclines.

\section{Adjuvant HER2/neu-targeted therapy}

HER2/neu positivity must be confirmed as a requirement for treatment with Trastuzumab; this is defined as an immuno-histochemical protein over-expression score of $3+$ or gene amplification demonstrated through FISH (fluorescence in situ hybridisation). With chemotherapy containing taxanes, Trastuzumab therapy can commence simultaneously, otherwise up to 3 months after chemotherapy is complete [4]. All in all, the treatment lasts a year in 3-weekly intervals and is given as an infusion.

\section{What's new?}

Data from various studies indicates that the effectiveness of anti-HER2/neu treatment can be significantly increased by the combination of different targeted substances. The CHERLOB study, for example, demonstrated that neoadjuvant dual antiHER2 therapy with Trastuzumab plus Lapatinib (previously only approved in metastasised situations) achieved significantly higher PCR rates compared to Trastuzumab or Lapatinib alone ( 43.1 vs. $25.7 \%$ [Trastuzumab] or $27.8 \%$ [Lapatinib]). It was combined with chemotherapy containing anthracycline and taxane. However, the dual targeted therapies are not suitable for routine use in cases of early breast cancer.

\section{Adjuvant endocrine therapy}

A tumour is classed as hormone receptor-positive and therefore as endocrine-sensitive if $\geq 1 \%$ of the tumour cells exhibit oestrogen and/or progesterone receptors on immuno-histochemical testing. Patients with a hormone receptor-positive tumour should receive endocrine therapy following the completion of chemotherapy in accordance with their menopausal status [28]:

1. Pre-menopausal: Patients are given Tamoxifen $(20 \mathrm{mg} / \mathrm{d})$ for 5 years. In younger patients, a combination with a $\mathrm{GnRH}$ analogue for at least two to five years can be considered.

2. Post-menopausal: Patients are given Tamoxifen and/or an aromatase inhibitor (AI) in a variable sequence or as monotherapy $[29,30]$ :

- Up-front aromatase inhibitors: initial AI over 5 years.

- Switch/sequence therapy: Tamoxifen over 2-3 years, then AI; total duration of treatment 5 years.

- Inverse switch: AI over 2-3 years, then Tamoxifen; total duration of treatment 5 years.

- Extended adjuvant therapy: 5 years of Tamoxifen, then AI for a further 5 years.

\section{Adjuvant radiotherapy}

Adjuvant radiotherapy should start around four to six weeks after surgery (after the wound has healed) or - if chemotherapy has been given - after the chemotherapy is complete. HER2/neu-targeted therapy can be given in parallel to radiotherapy, despite the possible cardio-toxicity, provided there are no plans to deliver
Was ist neu?

Studien untersuchen derzeit die Wirksamkeit anthrazyklinfreier Schemata (z. B. 6 Zyklen Docetaxel und Cyclophosphamid) bei Patientinnen mit einem HER2/neu-negativen Mammakarzinom, um die Langzeitnebenwirkungen (v. a. Kardiotoxizität) der Anthrazykline zu vermeiden.

\section{Adjuvante HER2/neu-zielgerichtete Therapie}

Als Voraussetzung für eine Therapie mit Trastuzumab muss eine HER2/neu-Positivität nachgewiesen sein: diese ist definiert als immunhistochemische Protein-Überexpression Score 3+ oder eine durch FISH (Fluoreszenz-in-situ-Hybridisierung) nachgewiesene Genamplifikation. Bei taxanhaltiger Chemotherapie kann der Beginn der Trastuzumab-Therapie simultan erfolgen, ansonsten bis zu 3 Monate nach Abschluss der Chemotherapie [4]. Insgesamt beträgt die Therapiedauer 1 Jahr in 3-wöchentlichen Intervallen als Infusion.

\section{Was ist neu?}

Daten verschiedener Studien geben den Hinweis, dass die Wirksamkeit einer Anti-HER2/neu-Therapie durch die Kombination verschiedener zielgerichteter Substanzen signifikant erhöht werden kann. So konnte die CHERLOB-Studie zeigen, dass die neoadjuvante duale Anti-HER2-Therapie mit Trastuzumab plus Lapatinib (bislang nur in metastasierter Situation zugelassen) gegenüber Trastuzumab oder Lapatinib allein deutlich höhere pCR-Raten bewirkte (43,1 vs. 25,7\% [Trastuzumab] bzw. 27,8\% [Lapatinib]). Kombiniert wurde mit einer anthrazyklinund taxanhaltigen Chemotherapie. Die dual zielgerichteten Therapien sind allerdings noch nicht für den Routineeinsatz beim frühen Mammakarzinom geeignet.

\section{Adjuvante endokrine Therapie}

Ein Tumor gilt als hormonrezeptorpositiv und damit als endokrin sensitiv, wenn $\geq 1 \%$ der Tumorzellen immunhistochemisch Östrogenund/oder Progesteronrezeptoren aufweisen. Patientinnen mit einem hormonrezeptorpositiven Tumor sollen nach Abschluss der Chemotherapie endokrin je nach Menopausenstatus behandelt werden [28]:

1. Prämenopause: Patientinnen erhalten Tamoxifen $(20 \mathrm{mg} / \mathrm{d})$ für 5 Jahre. Bei jüngeren Patientinnen kann eine Kombination mit einem GnRH-Analogon für mindestens 2 bis 5 Jahre erwogen werden.

2. Postmenopause: Patientinnen erhalten Tamoxifen und/oder einen Aromatasehemmer (AH) in variabler Sequenz oder als Monotherapie $[29,30]$ :

- Up-Front Aromatasehemmer: initial AH über 5 Jahre.

- Switch/Sequenz-Therapie: Tamoxifen über 2-3 Jahre, danach AH; Gesamttherapiedauer von 5 Jahre.

- Inverser Switch: AH über 2-3 Jahre, danach Tamoxifen; Gesamttherapiedauer 5 Jahre.

- Erweiterte adjuvante Therapie: 5 Jahre Tamoxifen, danach $\mathrm{AH}$ für weitere 5 Jahre.

\section{Adjuvante Strahlentherapie}

Die adjuvante Strahlentherapie sollte etwa 4 bis 6 Wochen nach der Operation (nach abgeschlossener Wundheilung) oder - sofern eine Chemotherapie durchgeführt wurde - nach Abschluss der Chemotherapie starten. Die HER2/neu-zielgerichtete Therapie kann trotz einer möglichen Kardiotoxizität parallel zur Strahlentherapie ver- 
radiation to the lymph drainage system of the internal mammary artery [31].

After every breast-conserving operation, follow-on radiotherapy of the entire breast is indicated to prevent local recurrence [32, 33]. The total radiation dose, which is calculated on an individual basis, is delivered over around 4-6 weeks (approx. 50 Gy in conventional fractionations $(5 \times 1.8-2.0 \mathrm{~Gy} /$ week $)$ [33]. To further reduce the rate of local recurrence [34], it is possible to deliver a boost dose of radiation to the tumour bed (the recommended boost dose is $10-16 \mathrm{~Gy}$, fractionated into $5 \times 1.8-2.0 \mathrm{~Gy} /$ week); the radiotherapy is consequently prolonged by 7 to 10 days. Alternatively, the boost radiation can be carried out during surgery while the wound is still open (IORT = intraoperative radiotherapy) [13].

Following mastectomy, it may be necessary in certain cases to irradiate the chest wall where several lymph nodes are involved $(\mathrm{pN}+[>3])$, in the case of T3/T4 tumours or following an R1/R2 resection [35]. Whether thorax wall irradiation is indicated even for early tumour stages is the subject of controversial discussion.

\section{Metastatic breast cancer}

Treatment in metastatic situations focuses primarily on increasing and preserving quality of life and maintaining physical and mental integrity. It should always be geared towards the patient's wishes. The aim is to reduce the tumour burden and keep the toxicity of the treatment as minimal as possible. A biopsy of the metastasis to further determine the hormone receptors and HER2 status is recommended in order to spot any possible discrepancy in the tumour characteristics between the primary tumour and the metastasis $[4,36]$. This leads to a change in strategy in around $18 \%$ of cases [37]. The most important predictive factor for metastatic breast cancer is the response to previous therapies. The response to therapy is monitored using imaging methods or by monitoring tumour markers. Studies use the detection and progress of circulating tumour cells in the blood.

\section{Treatment of metastatic breast cancer}

For hormone-sensitive cancers, endocrine therapy is generally given [38]. In pre-menopausal patients, GnRH analogues and Tamoxifen are used [39]; where there is treatment failure, GnRH analogues are also combined with aromatase inhibitors or treatment is given with Fulvestrant [40]. In post-menopausal patients, aromatase inhibitors or Tamoxifen is given, depending on the treatment given previously [41].

In cases of hormone receptor-negative breast cancer or following failed endocrine therapy with an acute threat to life and/or symptoms, chemotherapy is indicated. Essentially, monochemotherapy should be the treatment of choice. Where there is a strong need for remission due to life-threatening metastases or advanced metastatic-related symptoms, however, polychemotherapy should be used.

In cases of HER2-positive breast cancer, both the monoclonal antibodies Trastuzumab and the tyrosine kinase inhibitor Lapatinib are available as HER2-targeted therapies. Trastuzumab can be given both in combination with endocrine therapy and with taxanes, platin-containing substances, Vinorelbine and other substances. With Lapatinib, oral therapy is possible in cases of advanced or metastasised HER2-positive breast cancer, for example in combination with Capecitabin, as well as with endocrine therapy. In some cases, it is also possible to combine Trastuzumab and Lapatinib. abreicht werden, sofern keine Bestrahlung des Mammaria-internaLymphabflusses vorgesehen ist [31].

Nach jeder brusterhaltenden Operation ist eine Nachbestrahlung der gesamten Brust zur lokalen Rezidivprophylaxe indiziert $[32,33]$. Die individuell berechnete Gesamtstrahlendosis wird in etwa 20 Sitzungen über die Dauer von ca. 4-6 Wochen verabreicht (ca. 50 Gy in konventioneller Fraktionierung ( $5 \times 1,8-2,0 \mathrm{~Gy} /$ Woche) [33]. Zur weiteren Senkung der Rate an Lokalrezidiven [34] besteht die Möglichkeit einer sog. Boost-Bestrahlung im Tumorbett (empfohlene BoostDosis beträgt 10-16 Gy, fraktioniert in 5 × 1,8-2,0 Gy/Woche); die Bestrahlungszeit verlängert sich dadurch um 7 bis 10 Tage. Alternativ kann die Boost-Bestrahlung während der Operation bei noch offener Wunde durchgeführt werden (IORT = intraoperative Radiotherapie) [13].

Nach einer Mastektomie kann es in ausgewählten Fällen erforderlich sein, die Brustwand zu bestrahlen: bei Befall mehrerer Lymphknoten ( $\mathrm{pN}+$ [>3]), bei T3/T4-Tumoren oder nach R1/R2-Resektion [35]. Ob bereits bei früheren Tumorstadien die Thoraxwandbestrahlung indiziert ist, ist Gegenstand einer kontroversen Diskussion.

\section{Metastasiertes Mammakarzinom}

Die Therapie im metastasierten Stadium fokussiert sich vor allem auf die Erhöhung und Aufrechterhaltung der Lebensqualität sowie der körperlichen und seelischen Integrität. Sie sollte sich stets am Wunsch der Patientin orientieren. Ziel ist, die Tumorlast zu verringern und dabei die Toxizität der Therapie so gering wie möglich zu halten. Eine Biopsie der Metastase zur nochmaligen Bestimmung der Hormonrezeptoren und des HER2-Status wird empfohlen, um eine mögliche Diskrepanz in der Tumorcharakteristik zwischen Primärtumor und Metastase zu erkennen $[4,36]$. Dies führt in ca. $18 \%$ der Fälle zu einer Strategieänderung [37]. Wichtigster prädiktiver Faktor beim metastasierten Mammakarzinom ist das Ansprechen auf die vorherigen Therapien. Die Kontrolle des Therapieansprechens erfolgt anhand bildgebender Verfahren oder durch Kontrolle von Tumormarkern. In Studien findet der Nachweis und Verlauf zirkulierender Tumorzellen im Blut Anwendung.

\section{Therapie des metastasierten Mammakarzinoms}

Bei hormonsensitiver Erkrankung wird in aller Regel eine endokrine Therapie durchgeführt [38]. Bei prämenopausalen Patientinnen kommen GnRH-Analoga und Tamoxifen zum Einsatz [39]; bei Therapieversagen werden GnRH-Analoga auch mit Aromatase-Inhibitoren kombiniert oder mit Fulvestrant behandelt [40]. Bei postmenopausalen Patientinnen werden je nach Vorbehandlung Aromatase-Inhibitoren oder Tamoxifen eingesetzt [41].

Beim hormonrezeptornegativen Mammakarzinom oder nach einer erfolglosen endokrinen Therapie mit akuter Lebensbedrohung und/ oder Symptomatik ist die Chemotherapie indiziert. Grundsätzlich sollte eine Monochemotherapie bevorzugt werden. Bei hohem Remissionsdruck aufgrund lebensbedrohlicher Metastasen oder ausgeprägten metastasenbedingten Beschwerden kommt hingegen eine Polychemotherapie zum Einsatz.

Beim HER2-positiven Mammakarzinom stehen als HER2-zielgerichtete Therapien sowohl der monoklonale Antikörper Trastuzumab als auch der Tyrosinkinase-Inhibitor Lapatinib zur Verfügung. Trastuzumab kann sowohl in Kombination mit einer endokrinen Therapie als auch mit Taxanen, platinhaltigen Substanzen, Vinorelbin und anderen Substanzen verabreicht werden. Mit Lapatinib ist eine orale Therapie beim fortgeschrittenen oder metastasierten HER2-positiven Mammakarzinom möglich, beispielsweise in Kombination mit Capecitabin sowie auch mit einer endokrinen Therapie. In einigen Fällen ist auch die Kombination von Trastuzumab und Lapatinib möglich. 


\section{What's new?}

At the San Antonio Breast Cancer Symposium in 2011, Baselga et al. presented the findings of the CLEOPATRA study. This study compared the treatment regimes of Docetaxel and Trastuzumab vs. Docetaxel, Trastuzumab and Pertuzumab in patients with HER2/neu-positive advanced or metastatic breast cancer. The study showed a significant prolongation of progression-free survival by 6.1 months in patients who received dual HER2/neu blockade. Pertuzumab is a monoclonal antibody that binds to a different epitope of the extracellular HER2 domain than Trastuzumab. Pertuzumab therefore prevents the dimerisation of HER2/neu with other HER receptors.

\section{Bone metastases}

Bisphosphonates are the therapy of choice for tumour-related hypercalcaemia, osteolytic metastases, metastasis-related bone pain and tumour therapy-induced manifest osteoporosis [42].

\section{What's new?}

One alternative to the bisphosphonates is Denosumab, an antibody that targets the RANK ligand. Last year, the data from a phase III study involving breast cancer with bone metastases was presented. The patients were given either Denosumab (120 mg sc every 4 weeks) or Zoledronic acid (4 mg iv every 4 weeks). Denosumab was significantly more successful at reducing skeleton-related events and at prolonging the interval until the occurrence of the first skeletal complications [43]. Denosumab was approved in July 2011 in Europe for the indication of bone metastases.

\section{Obesity}

Obese women develop breast cancer significantly more frequently than women of normal weight [44]. Body weight influences the diagnosis of breast cancer: the detection rate is lower in obese patients and the tumours are on average larger on first diagnosis than in patients of normal weight [45]. The risk of recurrence is also demonstrably higher in obese patients than in women with a lower BMI [46].

All patients with breast cancer should therefore be encouraged to achieve a normal body weight [47]. Whether lifestyle modifications in terms of specific instructions to take regular physical exercise and nutritional advice can help reduce the risk of recurrence, is currently the subject of ongoing studies (e.g. the SUCCESS C study).

\section{Aftercare}

The aftercare of patients with breast cancer involves regular follow-ups: in the first three years, a physical examination is carried out every three months, and in the fourth and fifth years every six months and at yearly intervals thereafter [48]. Following breastconserving therapy, a mammogram and ultrasound should be carried out in the area of the ipsilateral breast every six months for the first, second and third years. The contralateral breast should be screened every year with mammography; this also applies to patients who have had one-sided mastectomies [13]. Breast ultrasound represents a useful supplementary investigation, especially in the case of architectural defects in the mammography.

\section{Was ist neu?}

Beim San Antonio Breast Cancer Symposium 2011 stellten Baselga et al. die Ergebnisse der CLEOPATRA-Studie vor. Hier wurden bei Patientinnen mit HER2/neu-positivem fortgeschrittenen oder metastasierten Mammakarzinom die Therapieregime Docetaxel und Trastuzumab vs. Docetaxel, Trastuzumab und Pertuzumab verglichen. Es zeigte sich eine signifikante Verlängerung des progressionsfreien Überlebens um 6,1 Monate bei Patientinnen, die die duale HER2/neu-Blockade erhielten. Pertuzumab ist ein monoklonaler Antikörper, der an ein anderes Epitop der extrazellulären HER2-Domäne bindet als Trastuzumab. So verhindert Pertuzumab die Dimerisierung von HER2/neu mit anderen HER-Rezeptoren.

\section{Knochenmetastasen}

Bisphosphonate sind die Therapie der Wahl bei tumorbedingter Hyperkalzämie, osteolytischen Metastasen, metastasenbedingtem Knochenschmerz und tumortherapieinduzierter manifester Osteoporose [42].

\section{Was ist neu?}

Eine Alternative zu den Bisphosphonaten ist der gegen RANKLigand gerichtete Antikörper Denosumab. Im vergangenen Jahr wurden die Daten einer Phase-III-Studie bei ossär metastasiertem Mammakarzinom vorgestellt. Die Patientinnen erhielten entweder Denosumab (120 mg s. c., alle 4 Wochen) oder Zoledronsäure (4 mg i.v. alle 4 Wochen). Denosumab war den Bisphosphonaten bez. Reduktion der skelettassoziierten Ereignisse sowie in der Verlängerung des Intervalls bis zum Auftreten der ersten skeletalen Komplikation signifikant überlegen [43]. Denosumab wurde im Juli 2011 in Europa für die Indikation ossärer Metastasen zugelassen.

\section{Adipositas}

Übergewichtige Frauen erkranken signifikant häufiger an Brustkrebs als normalgewichtige Frauen [44]. Das Körpergewicht beeinflusst die Brustkrebsdiagnostik: die Detektionsrate ist bei adipösen Patientinnen schlechter, und die Tumoren sind bei Erstdiagnose im Mittel größer als die bei normalgewichtigen Patientinnen [45]. Weiterhin ist das Rezidivrisiko bei adipösen Patientinnen nachweislich höher als bei Frauen mit einem niedrigeren BMI [46].

Bei allen Mammakarzinompatientinnen sollte folglich eine Normalisierung des Körpergewichts angestrebt werden [47]. Ob eine Lebensstilintervention im Sinne einer gezielten Anleitung zur regelmäßigen körperlichen Bewegung und einer Ernährungsberatung zu einer Senkung des Rezidivrisikos beitragen kann, ist Gegenstand aktueller Studien (z. B. SUCCESS-C-Studie).

\section{Nachsorge}

Die Nachsorge bei Mammakarzinompatientinnen umfasst regelmäßige Kontrolluntersuchungen: in den ersten 3 Jahren erfolgt eine körperliche Untersuchung im Abstand von 3 Monaten, im 4. und 5. Jahr alle 6 Monate und später in jährlichen Abständen [48]. Nach brusterhaltender Therapie sollte im 1. bis 3. Jahr im Bereich der ipsilateralen Brust halbjährlich eine Mammografie sowie Sonografie erfolgen. Die kontralaterale Brust sollte jährlich mittels Mammografie kontrolliert werden; dies gilt auch für einseitig mastektomierte Patientinnen 
The remaining aftercare is guided by symptoms, i.e. it relates solely to the local situation. Other instrument-guided diagnostics (e.g. liver ultrasound, bone scintigram, chest X-ray) and assays of tumour markers are only carried out if there is a clinical suspicion of metastases or if there is local recurrence. The current database has so far not demonstrated any advantage in terms of overall survival if metastasis is detected early $[49,50]$. This strategy may change, however, since the treatment of metastatic breast cancer has undergone significant improvements.

\section{Outlook}

The concepts for the treatment of breast cancer are undergoing constant change, which is shaped by the growing knowledge we have about tumour biology and the signal transduction pathways of tumour cells. The data regarding the increasingly restrictive approach to axillary dissection and the addition of molecular genetic subtypes as a supplement to classical prognostic and predictive factors call for new ways of thinking in everyday clinical practice.

\section{Conflict of Interest}

$\nabla$

W. Janni obtains fee and unrestricted research grants by Sanofi-Aventis, Novartis, Pfizer, AstraZeneca, Wilex, Veridex, Amgen, BoehringerIngelheim. B. Rack obtains unrestricted research grants by AstraZeneca, Chugai, Lilly, Novartis, Sanofi-Aventis, Tosoh, Veridex.

\section{References}

1 Goldhirsch A, Wood WC Coates AS et al. Strategies for subtypes - dealing with the diversity of breast cancer: highlights of the St. Gallen International Expert Consensus on the Primary Therapy of Early Breast Cancer 2011. Ann Oncol 2011; 22: 1736-1747

2 Scholzen T, Gerdes J. The Ki-67 protein: from the known and the unknown. J Cell Physiol 2000; 182: 311-322

3 Untch M, Gerber B, Möbus V et al. Zurich consensus: statement of German experts on St. Gallen conference 2011 on breast cancer (Zurich 2011). Geburtsh Frauenheilk 2011; 71: 381-390

4 AGO-Empfehlungen Gynäkologische Onkologie - Kommission Mamma. Deutsche Version 11.1.0. www.ago-online.org; last access: 7.11.2011

5 Cristofanilli M. Circulating tumor cells, disease progression, and survival in metastatic breast cancer. Semin Oncol 2006; 33 (3 Suppl. 9): S9S14

6 Rack B. Prognostic relevance of circulating tumor cells in the peripheral blood of primary breast cancer patients. SABCS 2010; Abstract S6-5

7 Hartkopf A, Banys M, Krawczyk N et al. Circulating tumor cells in earlystage breast cancer. Geburtsh Frauenheilk 2011; 12: 1067-1072

8 Kaufmann M, von Minckwitz G, Bear HD et al. Recommendations from an international expert panel on the use of neoadjuvant (primary) systemic treatment of operable breast cancer: new perspectives 2006. Ann Oncol 2007; 18: 1927-1934

9 Kaufmann M, Hortobagyi GN, Goldhirsch A et al. Recommendations from an international expert panel on the use of neoadjuvant (primary) systemic treatment of operable breast cancer: an update. J Clin Oncol 2006; 24: 1940-1949

10 Fisher B, Bryant J, Wolmark N et al. Effect of preoperative chemotherapy on the outcome of women with operable breast cancer. J Clin Oncol 1998; 16: 2672-2685

11 Kaufmann M. Long-term results from the neoadjuvant GeparDuo trial. J Clin Oncol 2010; 28 (Suppl.) (15 s): Abstract 537

12 Kaufmann M, von Minckwitz G, Smith R et al. International expert panel on the use of primary (preoperative) systemic treatment of operable breast cancer: review and recommendations. J Clin Oncol 2003; 21: 2600-2608

13 Kreienberg R, Kopp I, Albert U. Interdisziplinäre S3-Leitlinie für die Diagnostik, Therapie und Nachsorge des Mammakarzinoms, 2008. www. dggg.de/leitlinien; Stand: 7.11.2011
[13]. Die Mammasonografie stellt eine sinnvolle ergänzende Untersuchung, v.a. bei Architekturstörungen in der Mammografie dar. Die sonstige Nachsorge ist symptomorientiert, d.h. sie bezieht sich nur auf die lokale Situation. Weitere apparative Diagnostik (z. B. Lebersonografie, Knochenszintigramm, Röntgen-Thorax) sowie die Bestimmung von Tumormarkern werden lediglich bei klinischem Verdacht auf Metastasen oder bei einem Lokalrezidiv durchgeführt. Die uns heute vorliegende Datenbasis konnte bislang keinen Vorteil für das Gesamtüberleben zeigen, wenn eine Metastasierung früh erkannt wird $[49,50]$. Möglicherweise wird sich jedoch an dieser Strategie etwas ändern, da die Therapie des metastasierten Mammakarzinoms eine deutliche Verbesserung erfahren hat.

\section{Ausblick}

Die Konzepte der Behandlung des Mammakarzinoms unterliegen einem stetigen Wandel, der geprägt ist durch den Wissenszuwachs über die Tumorbiologie und die Signaltransduktionswege der Tumorzellen. Die Daten zum zunehmend restriktiven Vorgehen im Bereich der Axilladissektion sowie die Hinzunahme der molekulargenetischen Subtypen als Ergänzung zu den klassischen Prognose- und Prädiktionsfaktoren machen ein Umdenken im klinischen Alltag erforderlich.

\section{Interessenkonflikt \\ $\nabla$}

W. Janni erhält Honorare und uneingeschränkte Forschungszuschüsse von Sanofi-Aventis, Novartis, Pfizer, AstraZeneca, Wilex, Veridex, Amgen, Boehringer-Ingelheim. B. Rack erhält uneingeschränkte Forschungszuschüsse von AstraZeneca, Chugai, Lilly, Novartis, SanofiAventis, Tosoh, Veridex.

14 von Minckwitz G, Blohmer JU, Costa S et al. Neoadjuvant chemotherapy adapted by interim response improves overall survival of primary breast cancer patients - results of the GeparTrio trial. SABCS 2011; Abstract S3-2

15 O'Higgins N, Linos DA, Blichert-Toft $M$ et al. European Guidelines for Quality Assurance in the surgical Management of mammographically detected Lesions. In: Perry N et al., eds. European Guidelines for Quality Assurance in Breast Cancer Screening and Diagnosis. Office for Official Publications of the European Communities; 2006: 315-321

16 Fisher B, Anderson S, Bryant J et al. Twenty-year follow-up of a randomized trial comparing total mastectomy, lumpectomy, and lumpectomy plus irradiation for the treatment of invasive breast cancer. $\mathrm{N}$ Engl J Med 2002; 347: 1233-1241

17 Veronesi U, Cascinelli N, Mariani L et al. Twenty-year follow-up of a randomized study comparing breast-conserving surgery with radical mastectomy for early breast cancer. N Engl J Med 2002; 347: 12271232

18 Blamey RW. The role of the radiologist in breast diagnosis: a surgeon's personal view. Clin Radiol 1998; 53: 393-395

19 Blichert-Toft M, Smola MG, Cataliotti L et al.; on behalf of the European Society of Surgical Oncology. Principles and guidelines for surgeons management of symptomatic breast cancer. Ann Chir Gynaecol 1998; 87: 101-109

20 Palesty JA, Foster JM, Hurd TC et al. Axillary recurrence in women with a negative sentinel lymph node and no axillary dissection in breast cancer. J Surg Oncol 2006; 93: 129-132

21 Smidt ML, Janssen CM, Kuster DM et al. Axillary recurrence after a negative sentinel node biopsy for breast cancer: incidence and clinical significance. Ann Surg Oncol 2005; 12: 29-33

22 Fleissig A, Fallowfield LJ, Langridge CI et al. Post-operative arm morbidity and quality of life. Results of the ALMANAC randomised trial comparing sentinel node biopsy with standard axillary treatment in the management of patients with early breast cancer. Breast Cancer Res Treat 2006; 95: 279-293 
$23 \mathrm{Krag}$ DN, Anderson SJ, Julian TB et al. Primary outcome results of NSABP B-32, a randomized phase III clinical trial to compare sentinel node resection (SNR) to conventional axillary dissection (AD) in clinically node-negative breast cancer patients. J Clin Oncol 2010; 28 (18) (Suppl.): Abstract LBA505

24 Giuliano AE, Hunt KK, Ballman KV et al. Axillary dissection vs. no axillary dissection in women with invasive breast cancer and sentinel node metastasis: a randomized clinical trial. JAMA 2011; 305: 569575

25 Galimberti V, Cole BF, Zurrida S et al.; International, and B.C.S.G.T.-Investigators. Update of International Breast Cancer Study Group trial 23-01 to compare axillary dissection versus no axillary dissection in patients with clinically node negative breast cancer and micrometastases in the sentinel node. SABCS 2011; Abstract S3-1

26 Henderson IC, Berry DA, Demetri GD et al. Improved outcomes from adding sequential Paclitaxel but not from escalating Doxorubicin dose in an adjuvant chemotherapy regimen for patients with node-positive primary breast cancer. J Clin Oncol 2003; 21: 976-983

27 Roche H, Fumoleau P, Spielmann M et al. Sequential adjuvant epirubicin-based and docetaxel chemotherapy for node-positive breast cancer patients: the FNCLCC PACS01 trial. J Clin Oncol 2006; 24: 5664-5671

28 Kaufmann M, Rody R. Breast cancer: reduced mortality by early detection and adjuvant therapy. Geburtsh Frauenheilk 2009; 69: 218-232

29 Boccardo F, Rubagotti A, Guglielmini P et al. Switching to anastrozole versus continued tamoxifen treatment of early breast cancer. Updated results of the Italian tamoxifen anastrozole (ITA) trial. Ann Oncol 2006; 17 (Suppl. 7): vii10-vii14

30 Coombes RC, Kilburn LS, Snowdon CF et al. Survival and safety of exemestane versus tamoxifen after 2-3 years' tamoxifen treatment (Intergroup Exemestane Study): a randomised controlled trial. Lancet 2007: 369: 559-570

31 Belkacemi Y, Laharie-Mineur H, Gligorov J et al. [Potential risk and benefit of the combination of trastuzumab to chemotherapy and radiation therapy in non-metastatic breast cancer]. Cancer Radiother 2007; 11: 266-275

32 Van de Steene J, Vinh-Hung V, Cutuli B et al. Adjuvant radiotherapy for breast cancer: effects of longer follow-up. Radiother Oncol 2004; 72 : 35-43

33 Clarke $R$. 21st century challenges in radiation protection and shielding: draft 2005 recommendations of ICRP. Radiat Prot Dosimetry 2005; 115 (1-4): $10-15$

34 Antonini N, Jones H, Horiot JC et al. Effect of age and radiation dose on local control after breast conserving treatment: EORTC trial 2288110882. Radiother Oncol 2007; 82: 265-271

35 Truong PT, Lee J, Kader HA et al. Locoregional recurrence risks in elderly breast cancer patients treated with mastectomy without adjuvant radiotherapy. Eur J Cancer 2005; 41: 1267-1277

36 Fasching PA, Fehm T, Janni Wet al. Breast cancer therapy - a state of the art review. Geburtsh Frauenheilk 2010; 11: 875-886

37 Thompson AM, Jordan LB, Quinlan $P$ et al. Prospective comparison of switches in biomarker status between primary and recurrent breast cancer: the Breast Recurrence In Tissues Study (BRITS). Breast Cancer Res 2010; 12: R92
38 Stockler M, Wilcken NR, Ghersi D et al. Systematic reviews of chemotherapy and endocrine therapy in metastatic breast cancer. Cancer Treat Rev 2000; 26: 151-168

39 Klijn JG, Biamey RW, Boccardo F et al. Combined tamoxifen and luteinizing hormone-releasing hormone (LHRH) agonist versus LHRH agonist alone in premenopausal advanced breast cancer: a meta-analysis of four randomized trials. J Clin Oncol 2001; 19: 343-353

40 Liedtke C, Wolf MK, Kiesel L. New concepts for targeted systemic therapy in breast cancer. Geburtsh Frauenheilk 2010; 70: 625-633

41 Mouridsen H, Gershanovich M, Sun Yet al. Superior efficacy of letrozole versus tamoxifen as first-line therapy for postmenopausal women with advanced breast cancer: results of a phase III study of the International Letrozole Breast Cancer Group. J Clin Oncol 2001; 19: 25962606

42 Rosen $L S$, Gordon D, Kaminski M et al. Zoledronic acid versus pamidronate in the treatment of skeletal metastases in patients with breast cancer or osteolytic lesions of multiple myeloma: a phase III, doubleblind, comparative trial. Cancer J 2001; 7: 377-387

43 Stopeck AT, Lipton A, Body IJ et al. Denosumab compared with zoledronic acid for the treatment of bone metastases in patients with advanced breast cancer: a randomized, double-blind study. J Clin Oncol, 2010; 28: 5132-5139

44 F. N. World Cancer Research Fund and American Institute for Cancer Research, ed. Physical activity and the prevention of cancer. A global perspective. Washington, DC: AICR; 2007

45 Andergassen $U$, Rack B, Annecke $K$ et al. Obesity and tumor characteristic sin nodal-positive early-stage breast cancer: Results of the German ADEBAR study. J Clin Oncol 2010; 28 (Suppl.): 15 s (Abstr. 591)

46 Chlebowski RT et al., Dietary fat reduction and breast cancer outcome: interim efficacy results from the Women's Intervention Nutrition Study. J Natl Cancer Inst 2006; 98: 1767-1776

47 Kleeberg UR. Körperliche Aktivität und Brustkrebs - Prävention und Nachsorge. Geburtsh Frauenheilk 2009; 69: 423-425

48 Khatcheressian JL, Wolff AC, Smith TJ et al. American Society of Clinical Oncology 2006 update of the breast cancer follow-up and management guidelines in the adjuvant setting. J Clin Oncol 2006; 24: 50915097

49 Palli D, Russo A, Saieva $C$ et al. Intensive vs. clinical follow-up after treatment of primary breast cancer: 10-year update of a randomized trial. National Research Council Project on Breast Cancer Follow-up. JAMA 1999; 281: 1586

50 The GIVIO Investigators. Impact of follow-up testing on survival and health-related quality of life in breast cancer patients. A multicenter randomized controlled trial. JAMA 1994; 271: 1587-1592

Deutschsprachige Zusatzinformationen online abrufbar unter: www.thieme-connect.de/ejournals/toc/gebfra. 